Asian J. Med. Biol. Res. 2016, 2 (4), 513-517; doi: 10.3329/ajmbr.v2i4.30990

\author{
Asian Journal of \\ Medical and Biological Research \\ ISSN 2411-4472 (Print) 2412-5571 (Online) \\ www.ebupress.com/journal/ajmbr
}

\title{
Article \\ Spectroscopic analysis of heavy metal in frozen shrimp from different seafood processing plants of Chittagong, Bangladesh
}

\author{
Mohammad Shaokat Ali ${ }^{1 *}$, Suvanker Saha ${ }^{1}$, Shamima Ahmed ${ }^{2}$, Md. Forhad Uddin ${ }^{3}$ and Nilufa Yeasmin ${ }^{4}$ \\ ${ }^{1}$ Department of Applied Chemistry and Chemical Technology, Faculty of Food Science and Technology, \\ Chittagong Veterinary and Animal Sciences University, Khulshi, Chittagong-4225, Bangladesh \\ ${ }^{2}$ Department of Food Processing and Engineering, Faculty of Food Science and Technology, Chittagong \\ Veterinary and Animal Sciences University, Khulshi, Chittagong-4225, Bangladesh \\ ${ }^{3}$ Department of Microbiology, University of Chittagong, Bangladesh \\ ${ }^{4}$ Department of Applied Food Science and Nutrition, Faculty of Food Science and Technology, Chittagong \\ Veterinary and Animal Sciences University, Khulshi, Chittagong-4225, Bangladesh
}

"Corresponding author: Mohammad Shaokat Ali, Department of Applied Chemistry and Chemical Technology, Faculty of Food Science and Technology, Chittagong Veterinary and Animal Sciences University, Khulshi, Chittagong-4225, Bangladesh. Phone: +8801825128942; E-mail: shaokat.fst@gmail.com

Received: 17 October 2016/Accepted: 15 November 2016/ Published: 29 December 2016

\begin{abstract}
This study is carried out to determine the level of three common heavy metals i.e. mercury (Hg), lead $(\mathrm{Pb})$ and cadmium $(\mathrm{Cd})$ from different branded frozen shrimp samples from different processing plants in Chittagong Metropolitan Area, Bangladesh. The level of heavy metals is investigated by using Atomic Absorption Spectrophotometer (AAS) in twenty different frozen shrimp samples from four different processing plants. The range of mean level of concentration $(\mathrm{mg} / \mathrm{kg})$ of mercury $(\mathrm{Hg})$, lead $(\mathrm{Pb})$ and cadmium $(\mathrm{Cd})$ are $0.011-0.042 \mathrm{mg} / \mathrm{kg}, 0.065-0.087 \mathrm{mg} / \mathrm{kg}$ and $0.024-0.081 \mathrm{mg} / \mathrm{kg}$ respectively. Lead $(\mathrm{Pb})$ has the highest mean concentration of $0.087 \mathrm{mg} / \mathrm{kg}$ while mercury has the lowest mean of $0.011 \mathrm{mg} / \mathrm{kg}$. The mean concentration of mercury $(\mathrm{Hg})$, lead $(\mathrm{Pb})$ and cadmium $(\mathrm{Cd})$ in shrimps was observed within the range of BSTI (Bangladesh Standards and Testing Institution) standards for aquatic foods.
\end{abstract}

Keywords: frozen shrimps; heavy metals; AAS

\section{Introduction}

Shrimp has good source in food consumed by human and other organisms. It is important role in the diet, because apart from supply of good source of high quality protein and vitamins, it also contains several dietary mineral such as calcium, iron etc. Minerals are group of nutrients needed by the body are commonly grouped as major mineral or trace minerals. These minerals are essential components which are required in biological activity of the enzyme in the body (Ravichandran et al., 2009). Mercury, cadmium and lead major problem related to environmental contaminants and are known because of their toxic, mutagenic and carcinogenic properties (Belitz et al., 2001). The contamination by heavy metal is one of real problem which human was exposed, can cause harmful effect on air, water, soil, plant and human health. Industrial waste, chemical structure of land and metal of mining can be considered as source of heavy metal pollution in aquatic environment (Turkmen et al., 2007; Vinodhini et al., 2008). The pollution of the marine ecosystem by heavy metals can be studied with concentrations of them in water, sediment or aquatic organism (Laboy-Nieves et al., 2001), only living organisms are able to assess the complex effects of contaminations that are bioavailable (Agah et al., 2007). Heavy metals still play an important role as pollutants affecting aquatic systems (Mitra $e t$ al., 2010). Some of the metals found in the fish might be essential as they play important role in biological system of the fish as well as in human being, some of them may also be toxic as might cause a serious damage 
in human health even in trace amount at a certain limit. The common heavy metals that are found in fish include copper, iron, zinc and manganese, mercury, lead and cadmium (Robisch et al., 1993; Fernandes et al., 2008). Toxic elements can be very harmful even at low concentration when ingested over a long time period.

Heavy metals are defined as all metals of atomic weight greater than sodium with specific gravity of more than 5.0. The term 'heavy metal' has been used extensively to describe metals that are environmental pollutants (Walker et al., 1982). Even though some metals are essential when taken up by organisms, their excessive presence will reverse the effect so that benefit becomes toxicity. Heavy metals can be critically important to the life processes of marine organisms. The non-essential heavy metals include cadmium, gold, lead, mercury, silver, and metals (including radio nuclides) of higher atomic weight (Rainbow, 1985).

Mercury is relatively ubiquitous, is present at trace levels in living organisms in both inorganic and organic forms. Its toxic effects have been highlighted by some cases of collective poisoning in people who consumed a large amount of fish (Renzoni et al., 1998; Chen et al., 2002). It is generally accepted that seafood represents one of the major sources of mercury in the human food chain. Marine organisms are able to accumulate this metal and its most toxic organic compounds by filtering their food from seawater.

Cadmium is a relatively rare earth element that is almost uniformly distributed in the earth's crust with an average concentration of $0.15-0.2 \mathrm{mg} / \mathrm{kg}$ and ubiquitously present in food, water and air (Passwater et al., 1983). Cadmium circulates in the blood primarily bound to the red cells. It is evidently bound partly to hemoglobin and partly to metallothionein. Cadmium is very efficiently retained in the organism and normally only a very small quantity is excreted daily. The main route of excretion is via the urine. Excretion is low, less than $0.01 \%$ of the total body burden per day. Cadmium can also be excreted through other routes (feces, saliva, and hair) but at a much lower rate than in the urine (Piscator, 1979). Long-term exposures with daily intakes of 300-480 $\mu \mathrm{g}$ of cadmium may cause renal tubular dysfunction.

In addition, the low solubility of lead salts restricts movement across cell membranes. Tetramethyl lead could be accumulated rapidly from water by the rainbow trout (Wong, 1975). Highest residues were found in the intestinal fat, skin and gills. There was no relation between species, feeding habits and size of fish and concentration of tetraalkyl lead in tissues (Moore et al., 1984).

\section{Materials and Methods}

\subsection{Sample collection}

About 20 frozen shrimp samples were collected from 4 different seafood processing plants under Chittagong Metropolitan Area, Bangladesh. Then the samples were supplied directly for laboratory analysis.

\subsection{Sample preparation}

For analysis, the frozen shrimp sample were defrosted for $2 \mathrm{~h}$, it was then weighed into a pre weighed petri-dish, and then dried at $80^{\circ} \mathrm{C}$ in hot air oven. The dried samples weight were taken and recorded at intervals of $4 \mathrm{~h}$ until a constant weight was obtained. Then the dried sample was transferred into a pre-heated muffle furnace at $550^{\circ} \mathrm{C}$ for ashing. Then the ash was mixed into nitric acid $\left(\mathrm{HNO}_{3}\right)$ solution. 200 Perkin Elmer atomic absorption spectrophotometer model was used to analyze the concentration $(\mathrm{mg} / \mathrm{kg})$ of heavy metals $(\mathrm{Hg}, \mathrm{Pb}$ and $\mathrm{Cd})$.

\subsection{Analytical procedure}

\subsubsection{Mercury (Hg)}

The mercury standard calibration plot $(0,2.5,5$, and $10 \mathrm{mg} / \mathrm{L})$ was prepared in $10 \mathrm{~mL}$ of acid mixture containing $1.5 \% \mathrm{HNO}_{3}$ and $1.5 \% \mathrm{H}_{2} \mathrm{SO}_{4}$. Nine milliliters of acid mixture were added to $1 \mathrm{~mL}$ of digested sample. Mercury was determined using an aqueous solution of $3 \%(w / v) \mathrm{NaBH}_{4}$ in a $1 \%(\mathrm{w} / \mathrm{v}) \mathrm{NaOH}$ solution freshly prepared and filtered as reducing agent. One to two drops of silicon antifoaming was dispensed into a reaction flask before introducing any solution. All solutions were stabilized by adding $500 \mu \mathrm{L}$ of $5 \% \mathrm{KMnO}_{4}$ solution before starting the determination.

\subsubsection{Lead $(\mathbf{P b})$}

A calibration curve $(0,5,10$ and $20 \mathrm{mg} / \mathrm{L})$ was prepared in $0.2 \% \mathrm{HNO}$ and samples were diluted 1:4. Aliquots of $10 \mu \mathrm{L}$ of digested samples were introduced directly into the graphite furnace with an equal volume of matrix modifier $\left(10 \mathrm{~g} / \mathrm{L}\right.$ of $\mathrm{NH}_{4} \mathrm{H}_{2} \mathrm{PO}_{4}$ prepared in $0.2 \%(\mathrm{v} / \mathrm{v})$ nitric acid and $0.1 \%$ Triton $\left.\mathrm{X}-100\right)$. 
2.3.3. Cadmium (Cd)

A calibration curve $(0,1,3$, and $5 \mathrm{mg} / \mathrm{L})$ was prepared in $0.2 \% \mathrm{HNO}_{3}$ and samples were diluted 1:4. Aliquots of $20 \mu \mathrm{L}$ of digested samples were introduced directly into a graphite furnace with an equal volume of matrix modifier (a mixture of $3.3 \% \mathrm{Pd}$ and $0.03 \% \mathrm{Mg}$ as nitrates in $0.2 \% \mathrm{HNO}_{3}$ ).

\section{Results}

\subsection{Mercury (Hg)}

In this study, SS-I (Shrimp sample-I) had the lowest average level of mercury $(\mathrm{Hg})$ concentration $0.011 \mathrm{mg} / \mathrm{kg}$ while the SS-II (Shrimp sample-II) had the highest average level $0.042 \mathrm{mg} / \mathrm{kg}$. The mean value of average mercury $(\mathrm{Hg})$ concentration was $0.026 \pm 0.01$.

\subsection{Lead $(\mathbf{P b})$}

In SS-I (Shrimp sample-I) no detectable level of lead $(\mathrm{Pb})$ was observed. The SS-II (Shrimp sample-II) had the highest average level of lead $(\mathrm{Pb})$ concentration $0.087 \mathrm{mg} / \mathrm{kg}$ while the SS-IV (Shrimp sample-IV) had the lowest $0.065 \mathrm{mg} / \mathrm{kg}$. The mean value of average lead $(\mathrm{Pb})$ concentration was $0.077 \pm 0.01$.

\subsection{Cadmium (Cd)}

The SS-I (Shrimp sample-I) had the highest average level of cadmium $(\mathrm{Cd})$ concentration $0.081 \mathrm{mg} / \mathrm{kg}$ while the SS-III (Shrimp sample-III) had the lowest $0.024 \mathrm{mg} / \mathrm{kg}$. The mean value of average cadmium $(\mathrm{Cd})$ concentration was $0.043 \pm 0.02$.

The overall observation on the heavy metal level of these selected frozen shrimp as in table 1 and table 2 showed that all the samples fell below the BSTI recommended level of heavy metal concentrations. The mean value of these heavy metal concentrations can be shown by graphical representation as Figure 1.

Table 1. Evaluated concentrations of heavy metals in total frozen shrimp.

\begin{tabular}{llll}
\hline Sample ID & Mercury $(\mathbf{H g}) \mathbf{~ m g} / \mathbf{k g}$ & Lead $(\mathbf{P b}) \mathbf{~ m g} / \mathbf{k g}$ & Cadmium $(\mathbf{C d}) \mathbf{m g} / \mathbf{k g}$ \\
\hline 1. SS-Ia & 0.01 & Nil & 0.08 \\
2. SS-Ib & 0.01 & Nil & 0.085 \\
3. SS-Ic & 0.005 & Nil & 0.08 \\
4. SS-Id & 0.02 & Nil & 0.082 \\
5. SS-Ie & 0.01 & Nil & 0.079 \\
6. SS-IIa & 0.049 & 0.09 & 0.088 \\
7. SS-IIb & Nil & 0.085 & 0.01 \\
8. SS-IIc & Nil & 0.088 & 0.011 \\
9. SS-IId & 0.04 & 0.081 & 0.015 \\
10. SS-IIe & 0.037 & 0.089 & 0.014 \\
11. SS-IIIa & 0.03 & 0.08 & 0.017 \\
12. SS-IIIb & 0.031 & 0.082 & 0.022 \\
13. SS-IIIc & 0.033 & 0.081 & 0.025 \\
14 SS-IIId & 0.033 & 0.075 & 0.029 \\
15. SS-IIIe & 0.03 & 0.079 & 0.025 \\
16. SS-Iva & 0.022 & 0.065 & 0.04 \\
17. SS-IVb & 0.02 & Nil & 0.045 \\
18. SS-IVc & 0.023 & 0.06 & 0.038 \\
19. SS-IVd & 0.022 & Nil & 0.035 \\
20. SS-IVe & 0.02 & 0.069 & 0.041 \\
\hline
\end{tabular}

Table 2. The mean value of average concentration of heavy metals in frozen shrimp.

\begin{tabular}{lllcll}
\hline Heavy Metals & \multicolumn{3}{c}{ Samples } & Mean \pm SD \\
\cline { 2 - 5 } & SS-I & SS-II & SS-III & SS-IV & \\
\hline Mercury $(\mathrm{Hg})$ & 0.011 & 0.042 & 0.031 & 0.021 & $0.026 \pm 0.01$ \\
Lead $(\mathrm{Pb})$ & Nil & 0.087 & 0.079 & 0.065 & $0.077 \pm 0.01$ \\
Cadmium $(\mathrm{Cd})$ & 0.081 & 0.028 & 0.024 & 0.040 & $0.043 \pm 0.02$ \\
\hline
\end{tabular}




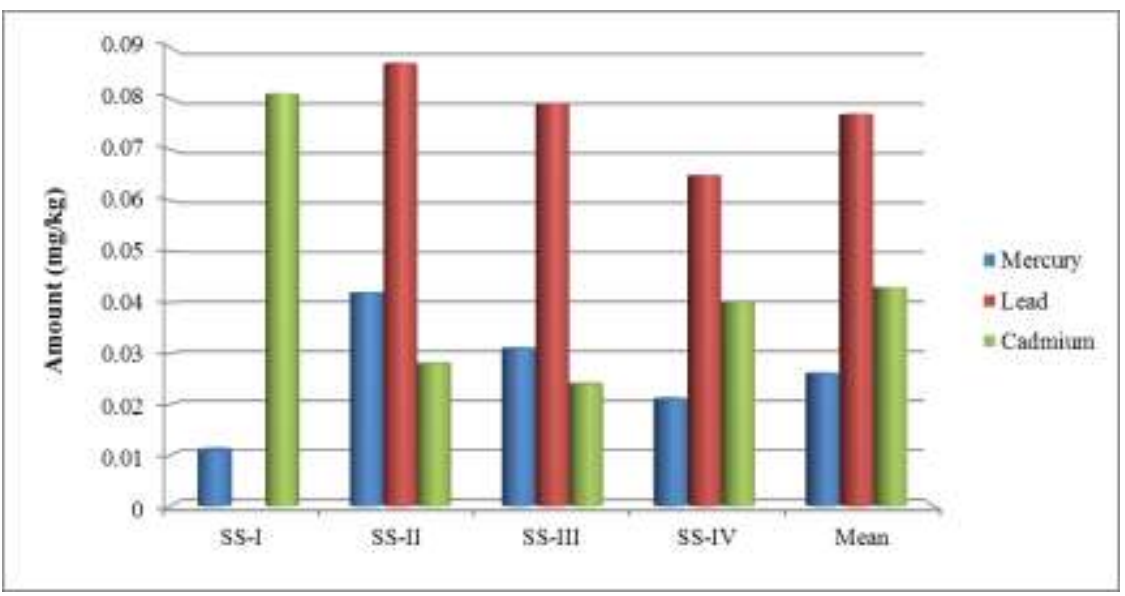

Figure 1. Mean value of heavy metal concentration.

\section{Discussion}

The levels of heavy metals in these frozen shrimp samples followed a uniform pattern as some confirmed to the BSTI permissible levels for heavy metals in food samples. The SS-I (Shrimp Sample-I) contained no lead $(\mathrm{Pb})$ content in the flesh. The mean level of concentration $(\mathrm{mg} / \mathrm{kg})$ of mercury $(\mathrm{Hg})$, lead $(\mathrm{Pb})$ and cadmium $(\mathrm{Cd})$ are $0.026 \pm 0.01 \mathrm{mg} / \mathrm{kg}, 0.077 \pm 0.01 \mathrm{mg} / \mathrm{kg}$ and $0.043 \pm 0.02 \mathrm{mg} / \mathrm{kg}$ respectively. However, these low levels do not exclude the risk of bioaccumulation in these crustaceans which are known to be bioaccumulative species. Heavy metals are major contaminants of the marine environment. Some, called trace elements $(\mathrm{Fe}, \mathrm{Cu}, \mathrm{Zn}, \mathrm{Mn}, \mathrm{Mo}$, Co) are essential to the functioning of metalloenzymes, but can become toxic at high concentrations. Others, such as $\mathrm{Hg}, \mathrm{Cd}$ and $\mathrm{Pb}$, are only known for their toxic effects. Heavy metals can alter the physiology of organisms in several ways, either by their binding to soluble biomolecules (enzymes, DNA) or membrane (phospholipids) or reacting with thiol groups ( $\mathrm{SH}$ ) biomolecules.

This study result revealed that the maximum level of mercury $(\mathrm{Hg})$, lead $(\mathrm{Pb})$ and cadmium $(\mathrm{Cd})$ of these selected frozen shrimp samples were $0.042 \mathrm{mg} / \mathrm{kg}, 0.087 \mathrm{mg} / \mathrm{kg}$ and $0.081 \mathrm{mg} / \mathrm{kg}$ respectively which fell below the BSTI recommended level.

\section{Conclusions}

The result found in this elemental analysis was under the BSTI permissible limit. Hence the heavy metal compositions of the selected shrimp samples, might not pose any immediate serious health effect given their accumulation in the human body but long time accumulation of these metals could lead to health issues.

\section{Acknowledgements}

The authors would gratefully like to acknowledge the laboratory support given by theBangladesh Council of Scientific and Industrial Research (BCSIR), Chittagong.

\section{Conflict of interest}

None to declare.

\section{References}

Agah H, M Leermakers, M Elskens, SM Fatemi and W Baeyens, 2007. Total mercury and methyl mercury concentrations in fish from the Persian Gulf and the Caspian Sea. Water, Air, \& Soil Pollution, 181: 95-105.

Belitz HD, W Grosch and P Schieberle, 2001. Lehrbuch der Lebensmittelchemie. Berlin:Springer, ISBN 3-5404109615.

Chen CY, N Serrell, DC Evers, BJ Fleishman, KF Lambert, J Weiss, RP Mason and MS Bank, 2002. Meeting report: Methylmercury in marine ecosystems-from sources to seafood consumers. Environmental Health Perspectives, 116: 1706-1712.

Fernandes C, A Fontainhas-Fernandes, D Cabral and MA Salgado, 2008. Heavy metals in water, sediment and tissues of Liza saliensfrom Esmoriz-Paramos lagoon, Portugal. Environ. Monit. Assess., 136: 267-275.

Laboy-Nieves EN and JE Conde, 2001. Metal levels in eviscerated tissue of shallow water deposit feeding holothurians. Hydrobiologia, 459: 19-26. 
Mitra A, K Mondal and K Banerjee, 2010. Concentration of Heavy Metals in Fish Juveniles of Gangetic Delta of West Bengal. Indian Journal of Fisheries and Hydrobiology, 5: 21-26.

Moore JW and S Ramamoorthy, 1984. Heavy metals in natural waters. Springer-Verlag, pp. 268.

PasswaterRA and EM Cranton, 1983. Trace Elements, Hair Analysis, and Nutrition.KeatsPublishing Company, New Canaan, Connecticut.

Piscator M, 1979. Handbook on the toxicology of metals, Amsterdam, Elsevier/North Holland Biomedical Press, pp. 613-626.

Rainbow PS, 1985. Accumulation of $\mathrm{Zn}, \mathrm{Cu}$ and $\mathrm{Cd}$ by crabs and barnacles. Estuarine, Coastal and Shelf Science, 21: 669-686.

Ravichandran S, G Rameshkumar and A Rosario-Prince, 2009. Biochemical Composition of Shell and Flesh of the Indian White Shrimp Penaeusindicus. American-Eurasian Journal of Scientific Research, 4: 191-194.

Renzoni A, F Zino and E Franchi, 1998.Mercury levels along the food chain and risk for exposed populations. Environmental Research, 77: 68-72.

Robisch PA and RC Clark, 1993. Sample preparation and analyses of trace metals by atomic absorption spectroscopy. In GG, Lauenstein and AY, Cantillo (editors), Sampling and Analytical Methods of the National Status and Trends Program, National Benthic Surveillance and Mussel Watch Project 1984-1992, vol. III. Comprehensive descriptions of elemental analytical methods, U.S. Dep. Commer., NOAA Tech. Memo. NOS. ORCA, 71: 111-150.

Turkmen M and C Ciminli, 2007. Determination of metals in fish and mussel species by inductively coupled plasma-atomic emission spectrometry. Food Chem., 103: 670-675.

Vinodhini R and M Narayanan, 2008. Bioaccumulation of heavy metals in organs of fresh water fish Cyprinuscarpio. Int. J. Environ. Sci. Tech., 5: 179-182.

Walker J, SM Gentile, JH Gentile and JF Helthshe, 1982. Chronic effects of cadmium on two species of mysid shrimp: Mysidopsisbahia and Mysidopsisbiglowi. Hydrobiologia, 93: 195-204.

Wong PT, 1975. Methylation of lead in the environment. Nature, 253: 263-264. 